MAX-PLANCK-INSTITUT FÜR WISSENSCHAFTSGESCHICHTE

Max Planck Institute for the History of Science

2015

PREPRINT 470

Fidel Castro Díaz-Balart

On the Development of Nuclear Physics in Cuba 



\section{ON THE DEVELOPMENT OF NUCLEAR PHYSICS IN CUBA}

Fidel Castro Díaz-Balart

Vice-president of the Academy of Sciences of Cuba

ABSTRACT: This article summarizes a historical perspective on the nation's experience in the development of nuclear physics, with a special emphasis on its relationship with the Cuban Nuclear Program and the scientific and technological achievements attained as well as their social and economic impact. The development of nuclear energy and nuclear facilities requires the creation of specialized institutions, the training of professionals in the field, the structuring of interdisciplinary groups made up of nuclear physicists and specialists in theoretical and experimental physics, and engineers and specialists in other areas. This article also addresses the multiple peaceful applications introduced in Cuba, particularly those related to the scientific nuclear program.

\section{Introduction}

Giving an overview of the origin and development in Cuba of nuclear physics and other associated technologies in the context of the twentieth anniversary of the Nuclear Energy and Advanced Technologies Agency (AENTA) is not an easy task.

Nowadays it is quite common to find multidisciplinary groups made up of young scientists in which there is an outstanding presence of nuclear physicists, for instance at the European Organization for Nuclear Research (CERN) in Geneva; the Joint Institute for Nuclear Research (IUIN) in Dubna; the International Centre for Theoretical Physics(ICTP) in Trieste; the Centre for Heavy lon Research (GSI) in Darmstadt; and the Frankfurt Institute for Advanced Studies (FIAS), as well as others associated with different specialized laboratories of the International Atomic Energy Agency (IAEA). It is similarly common today to find such groups engaged in state-of-the-art research and innovation at prestigious universities, research institutes and high-tech companies in the Americas, Europe and Asia. It is very encouraging to see that numerous scientific articles and patents make reference to their results, their participation in renowned scientific conferences and the national and international awards granted to them. The 
number of university graduates in this specialty, and of those holding a master's or a PhD degree in other fields associated with nuclear physics and working in the Science, Technology and Innovation (STI) sector in our country and beyond its borders is also noteworthy.

But how was this laborious and complex Cuban nuclear pathway carved out and developed?

In a nutshell, Section 1 offers an overview of the development of nuclear physics in Cuba, particularly the catalyst role played by the Cuban Nuclear Program (PNC), as well as the initial steps taken during the 1940s and 1950s, the institutions that were created, and the most outstanding activities carried out in this field from 1959 until the late 1970s. Some of the landmarks in this process were the historical context and the outstanding events that promoted work in the field of physics and all other nuclear research from the 1980s on. Section 2 deals with the applications of nuclear technologies that had the greatest social and economic impact. This section includes a description of the deeply rooted ties that exist between these and basic and applied nuclear physics research. It also covers the institutional context of the nuclear sector at each and every stage and provides a detailed description of the main activities carried out by national sectors, application areas and associated research and teaching institutions.

Section 3 summarizes the progressive introduction of multiple modern nuclear research programs and other studies of clear practical interest, which were made in theoretical as well as experimental nuclear physics to support the Juraguá nuclear power plant and to assimilate other, similar facilities. The beginning of the second stage is analyzed from the creation of AENTA, with a focus on the applications that raised greatest interest and on the previously established fundamental studies designed to support the social and economic development of the country up to the present.

Section 4 includes several reflections and lessons learned from the development of the peaceful uses of nuclear energy in Cuba, particularly from scientific program, which could serve as an example for other countries with similar conditions and levels of development that have begun to take their first steps toward a nuclear energy program. In this article, emphasis is placed on the fundamental role played by the support received from the former Soviet Union and other Eastern European states and the main international organizations in developing this sector in our country. 


\section{The Emergence and Development of the Cuban Nuclear Program}

The development of nuclear physics in Cuba as an inherent and indivisible part of physics in general is linked, as is the case for every other field of knowledge in our country, to the origins of Cuban science between the eighteenth and nineteenth centuries, ${ }^{1}$ when men like Félix Varela, Felipe Poey, Álvaro Reinoso, Carlos J. Finlay and Juan Tomás Roig were considered exceptions in the midst of the desolation and neglect faced by science in Cuba. Thus, the 1940s and 1950s marked the beginning of tentative use of radioactive resources, radiotherapy equipment and nuclear technologies in other areas, particularly in medicine, for the most part due, to the initiative and tenacity of a small group of conscientious and committed specialists. It would impossible to summarize within the narrow scope of this article the history of those incipient nuclear activities; much less would it be possible to provide a detailed account of those carried out during the 1960s and the 1970s - all of which are described in the book Energía nuclear y desarrollo (Nuclear Energy and Development), ${ }^{2}$ as well as in other related publications (Pérez Rojas, H. et al. ${ }^{3}$ ). However, in this article it is indispensable to address, albeit briefly, the context and certain realities that marked the fifteen decisive years preceding the creation of AENTA.

In keeping with the ideas of the historical leader of the country to turn Cuba into a country of men and women of science and thoughts, ${ }^{4}$ the work carried out by the Revolution in the areas of education and science during its first decade was impressive. One of the first institutions founded in the 1960s was the Academy of Sciences of Cuba (ACC), which acted as a catalyst for the creation of different scientific institutions, such as the National Institute of Oncology and Radiobiology (INOR), the National Scientific Research Center (CNIC) and the Institute of Animal Sciences (ICA), which were the pioneers in the use of ionizing radiation in biomedicine and other areas. Nevertheless, the utmost expression of what would ultimately become a firm national commitment to the development of this sector was the inauguration, by Fidel and Raúl Castro, of the Institute of Nuclear Physics (IFN) on 8 January 1969. During the $1970 \mathrm{~s}^{5}$ the IFN, which later became the Institute of Nuclear Research (ININ), with the cooperation of the IAEA and the United Nations Development Program (UNDP), completed assembling much of the basic equipment that had been supplied by the USSR (including a sub-critical reactor, radiochemical facilities, gamma radiation sources and neutron spectrometry analyzers) which, among other things, made it possible to analyze minerals, design 
applications for agriculture, and make use of Mossbauer spectroscopy, nuclear electronics and dosimetry. At CNIC certain nuclear techniques and basic instrumentation were developed for oil prospecting and characterizing the properties of ionizing radiation. Those years also witnessed the foundation of the National Commission for the Peaceful Use of Atomic Energy (CNUPEA) as well as the specialized nuclear departments at the University of Havana (UH), the Higher Polytechnic Institute José Antonio Echevarría (ISPJAE) and the School of Physics at the University of Oriente. ${ }^{6}$ Back then a UNDP project associated with the use of nuclear technology in the economy was also implemented.

All of these actions encouraged the training of professionals and the achievement of master's degrees in nuclear specialties and contributed to the initial conception of future development in this field.

In 1976, the construction of a nuclear power plant in Juraguá was part of an intergovernmental agreement signed with the USSR. Given its scale, the resources involved and its importance, it was considered "The Work of the Century" in Cuba. In order to face that great challenge, it was indispensable to integrate all efforts into a coherent national strategy, with well-defined objectives and priorities, and design a Cuban Nuclear Program (PNC) that was capable of creating a solid infrastructure in the interest of developing nuclear energy. At the end of 1979, based on the prior work that had been carried out by the Nuclear Group of the Secretariat of the Council of Ministers (CECM), important political and organizational decisions were made, leading to the proclamation of Decree 52, which was issued by the Executive Committee of the Council of Ministers.

\section{The Fifteen Decisive Years of the Cuban Nuclear Program}

In January 2015 it was 35 years since the restructuring of nuclear activity, after the creation of the Cuban Atomic Energy Commission and the Executive Secretariat for Nuclear Affairs (SEAN). ${ }^{7}$ The former was tasked with the enforcement of the policy that had been approved, and the coordination and control of the efforts of all the national bodies involved in nuclear activity. At that time SEAN was the institution in charge of implementing the approved policy and developing the scientific, technical and regulatory infrastructure and the training of the human capital that would be required in the new stage. $\mathrm{H}$. Blix, then director general of the IAEA, described the nuclear program that 
emerged from this new organization, as "impressive, strong and very well-structured."8 The program pursued five main goals: the development of nuclear energy, the creation of a radiological protection and nuclear safety system, the massive introduction of nuclear technology to different sectors; the promotion of basic and applied research, and the comprehensive training of the required specialists, middle-level technicians and workers.

What was achieved during that decade and a half is described in detail in the book Nuclear Energy: Environmental Danger or Solution for the Twenty First Century, ${ }^{9}$ but it would also be appropriate to refer briefly to the context and the period when the first pillars of the complex infrastructure demanded by the Cuban nuclear program were built in order to support research in nuclear physics and other related specialties. Those years witnessed the creation of the following centers: the Center for Radiation Protection and Hygiene (CPHR), Nuclear Safety Center (CSN), Center of Applied Studies for Nuclear Development (CEADEN), the Nuclear Energy Information Center (CIEN) and the Higher Institute of Nuclear Sciences and Technologies (ISCTN). The design and construction of the Center of Isotopes (CENTIS), which was inaugurated in 1995, also began during these years. Another major project to be developed was the Nuclear Research Center (CIN). By mid-1979, the Nuclear Group of the Secretariat of the Executive Committee of the Council of Ministers had been entrusted with the task of streamlining the existing conceptual ideas and obtaining from the USSR Government the necessary foreign credit to develop the first stage of the project. The project received due consideration, the credit was granted, and over the following decade the investments unit carried out the technical tasks and various project phases.

Construction continued up to the year 1992, when both this and the nuclear power plant project in Juraguá were interrupted.

Before concluding this section, two crucial aspects during that period should be mentioned: international politics and cooperation, and the training of human resources. As to the first, the emphasis should be on the active role played by Cuba in the IAEA. During the years 1981 and 1982, Cuba signed the three partial safeguards agreements that had remained pending and were required for permission to import the reactors that would launch operation in the course of the following decade. In 1983, Cuba was elected to the Board of Governors of that agency for the first time since its creation in 1957; it was re-elected again on four new occasions until very recently. Our country's 
work as president of the Non-Aligned Nuclear Group from 1983 to 1987 was very fruitful. Its participation in the commission representing Comecon (CMEA) during the 1980s was also worthy of recognition. ${ }^{10}$ Equally noteworthy was its contribution to the United Nations Conference for the Promotion of International Co-operation in the Peaceful Uses of Nuclear Energy held in Geneva in $1987 .{ }^{11}$ As to international support, it must be emphasized that this was significant. Its total amount exceeded 60 million USD, which included the acquisition of equipment and facilities supplied by the Comecon nations, funding offered by the IAEA and the UNDP - $87 \%$ of all the assistance that had been offered up to that time and for more than 30 years - plus the contribution of the bilateral agreements that were signed with the USSR and other Eastern European countries. In addition to all of this, the contribution offered by these prestigious scientific centers also enabled us to train more than 550 specialists from different national institutions and welcome a total of 120 international experts on visits to our country.

The impact of the selection and training of human resources for the Cuban nuclear program is evidenced by the following facts. In 1980, as a result of an initiative by SEAN and by virtue of the corresponding resolution issued by the Ministry of Education, the Pre-University Institutes Specialized in Exact Sciences (IPECE) were created. The first of them - "Humboldt 7" - and another two created in the provinces of Santiago de Cuba and Villa Clara during that five year period, became a major source of excellent graduates for the study of sciences and engineering in higher education, and a particularly valuable source of graduates for nuclear specialties. Suffice it to state that until they were merged with the former vocational schools in 1985, their graduates accounted for $28 \%$ of the total number of university students studying nuclear specialties. In those years, hundreds of mid-level technicians and skilled workers were also trained at the Electronuclear Polytechnic School of Juraguá in Cienfuegos, created in 1981.

As to higher education, up to the year 1980 a total of 48 professionals had graduated from nuclear specialties. Between 1980 and 1988, more than 650 specialists graduated from this level. ${ }^{12}$ In general, up to mid-1992, the total number of students graduated in the USSR, the Eastern European countries and Cuba in around 50 specialties, amounted to approximately 1,100 (no more students were sent abroad to study after 1990). In 1987 - after creation of the School of Nuclear Science and Technologies (FCTN) at the University of Havana in 1981 - the Higher Institute of Nuclear Sciences 
and Technologies (ISCTN) was founded. This small, well-equipped nuclear educational facility based its curriculum on internationally recognized quality standards and educational levels, training highly qualified professionals in the fields of nuclear physics, radiochemistry and nuclear engineering. The specialty of physical engineering was added afterwards. This university was tasked with the training of students in these specialties so that they could work at the nuclear power plant as well as in the scientific, technical and regulatory infrastructure that supported it and the development of nuclear applications. In 2003, the ISCTN was expanded to include the field of meteorology and became the Higher Institute of Applied Sciences and Technologies (INTEC), from which a total of 178 professionals have graduated so far.

Table 1 shows the total number of graduates in nuclear specialties since 1981, broken down according to academic years, specialties and their respective higher education institutions. Three hundred forty nuclear physicists and 45 physics engineers of these graduated from INTEC. If we take into account the approximately 120 students who graduated abroad in that specialty, the total number of professionals in the field would exceed 500. It's hardly surprising that, together with those physicists who graduated from crash courses back in the 1970 s, ${ }^{13}$ most of the professionals, master's degrees and $\mathrm{PhDs}$ in physics in our country are nuclear physicists.

Table 1. Total number of graduates in nuclear specialties broken down according to academic years, specialties and institutes of higher education

\begin{tabular}{|l|l|l|l|l|}
\hline Nuclear specialties & $\begin{array}{l}\text { School of } \\
\text { Nuclear } \\
\text { Sciences and } \\
\text { Technologies } \\
\mathbf{1 9 8 1 - 1 9 8 7}\end{array}$ & $\begin{array}{l}\text { Higher Institute of } \\
\text { Nuclear Sciences and } \\
\text { Technologies 1988/2003 } \\
\left(I^{2} \text { of them 1988-1992) }\right.\end{array}$ & $\begin{array}{l}\text { INTEC - } \\
\mathbf{2 0 0 3 - 2 0 1 4}\end{array}$ & $\begin{array}{l}\text { Total } \\
\text { graduates }\end{array}$ \\
\hline $\begin{array}{l}\text { Energy and nuclear } \\
\text { technologies } \\
\text { Engineering }\end{array}$ & $\mathbf{1 7 8}$ & $203 /^{2} 101$ & 126 & 507 \\
\hline Nuclear physics & $\mathbf{3 2}$ & $181 / /^{2} 76$ & 127 & 340 \\
\hline $\begin{array}{l}\text { Nuclear physics } \\
\text { engineering }\end{array}$ & $\mathbf{0}$ & $45 /^{2} 32$ & 0 & 45 \\
\hline Radiochemistry & $\mathbf{0}$ & $121 /{ }^{2} 29$ & 105 & 226 \\
\hline Total & $\mathbf{2 1 0}$ & $550 /^{2} 238$ & $\mathbf{3 5 8}$ & $\mathbf{1 1 1 8}$ \\
\hline
\end{tabular}

Source: Official registry of graduates of INSTEC

\footnotetext{
${ }^{1}$ The specialty was called Nuclear Energy.
} 
As far as research and postgraduate education are concerned, it should be emphasized that during the 1980s, organizing and hosting scientific seminars and national and international workshops was of great importance. The First, Second and Third Conferences about Current Problems of Nuclear Sciences held in 1980, 1985 and $1990^{14}$ stood out for their high level and scientific rigor. They were attended by representatives of analogous national institutions as well as by renowned high-level foreign lecturers. As of 2003, a total of 90 specialists have been granted master's degrees in nuclear physics, in eight different graduating classes -42 of them in theoretical aspects and 48 in experimental aspects, and 20 have earned a PhD.

As a result of the international geopolitical upheaval and the subsequent world crisis during the early years of the 1990s, at this time the main nuclear investments in the country were suspended and the Cuban nuclear program was slowed down.

Nevertheless, by that time a substantial part of an entire system of institutions in this field had already been structured and deployed. There was already a significant qualified workforce that made it possible to preserve the entire scientific and technological system of SEAN and, in particular, to preserve the human potential, which had been trained with so much effort. In 1994, the central administrative organs were reorganized. The Ministry of Science, Technology and the Environment was created by merging the already existent Academy of Sciences with SEAN. The AENTA was founded to accommodate the SEAN system, aside from its logistic infrastructure and its territorial chapters.

\section{Nuclear Technology Applications in Cuba}

The scientific and innovation activity in the field of nuclear physics can be grouped into three fundamental areas: theoretical research, experimental research and applied research. The accumulated knowledge and experience in the fields of experimental and theoretical nuclear physics, which are described in Section 3, have made it possible to address a wide range of applied and practical problems, which have yielded social and economic results.

At present there are around 160 institutions and sectors under different ministries which apply nuclear technologies and make use of radioactive sources; their results adhere closely to the IAEA Technical Cooperation and Training Program. The existence and 
development of an infrastructure covering a series of different fields such as human health (radiotherapy, nuclear medicine, the production of radiopharmaceuticals and the preclinical and clinical research of pharmaceuticals, including the technology of services to the biotechnology and pharmaceutical industry); applications in the areas of agriculture and sugar production, food production, mining and industry, as well as in studies related to water resources and the protection of marine and terrestrial environments, is already a fact. There is also a technical network for the control and detection of unauthorized radioactive and nuclear sources.

Certain applications are linked more directly to theoretical and experimental research in nuclear physics, most of which are carried out at CEADEN and INTEC. Table 2 shows the research carried out by the AENTA centers according to their different areas of application in social and economic sectors.

\section{Table 2. AENTA Centers, by Sector and Area of Application}

\begin{tabular}{|c|c|c|}
\hline SECTOR & INSTITUTION & ÁREA OF APPLICATION \\
\hline Health & $\begin{array}{l}\text { CENTIS } \\
\text { CEADEN }\end{array}$ & $\begin{array}{l}\text { Production of radiopharmaceuticals and pharmacokinetic } \\
\text { studies. } \\
\text { Radiosterilization (tissues, products for medicinal use) }\end{array}$ \\
\hline $\begin{array}{l}\text { Agriculture and } \\
\text { industry }\end{array}$ & $\begin{array}{l}\text { CEADEN } \\
\text { INSTEC }\end{array}$ & $\begin{array}{l}\text { Irradiation technologies (radiometagenesis of plants) } \\
\text { Gamma and neutron profiling (optimization of industrial } \\
\text { processes) }\end{array}$ \\
\hline Environment & $\begin{array}{l}\text { CEADEN } \\
\text { INSTEC }\end{array}$ & $\begin{array}{l}\text { X-ray fluorescence system (analytic determination of } \\
\text { environmental samples) } \\
\text { Neutron activation analysis and other related analytic } \\
\text { techniques (analytic determination of environmental } \\
\text { samples) }\end{array}$ \\
\hline Hydrology & $\begin{array}{l}\text { CPHR } \\
\text { INSTEC }\end{array}$ & $\begin{array}{l}\text { Natural radioactive tracers (dating of samples) } \\
\text { Tracers/radiotracers and non-radioactive tracer technology } \\
\text { (Hydrologic and hydrochemical characterization of } \\
\text { aquifers) }\end{array}$ \\
\hline Radiation safety & $\begin{array}{l}\text { CENTIS } \\
\text { CNSN } \\
\text { CPHR }\end{array}$ & $\begin{array}{l}\text { Metrology of radiation (measurement of activity) } \\
\text { Control of the sealed radiation sources (leak tightness) } \\
\text { Nuclear regulatory organ } \\
\text { Radioactive waste management; radioactive } \\
\text { decontamination of materials; metrology of radiation } \\
\text { (doses); foodstuffs and scrap radiological surveillance }\end{array}$ \\
\hline
\end{tabular}

Source: Based on the author's Influencia de las aplicaciones nucleares en la sociedad contemporánea ${ }^{15}$

The main applications described below are associated with the analytic and nucleonic methods used in applied nuclear physics, namely: neutron activation analysis (NAA), gamma spectrometry (GS), X-ray fluorescence (XRF), neutron reflection and moderation, beta backscattering, gamma transmission and absorption and the track 
etching technique. For the mathematical simulation of the interaction with radiation, the methods used were the Monte Carlo method, spectra deconvolution and multiple tools of theoretical nuclear physics. In the context of the Cuban nuclear program, and in particular when it comes to research with some economic interest, and the study of the elemental composition of multiple samples, the aspects analyzed were the following: the development and implementation of methods to measure the sections of concrete removed in Cuba and their characterization as radiation shields; ${ }^{16}$ the development of nuclear methods combining NAA and GS with XRF; the evaluation of the level of pollution resulting from the presence of heavy metals in marine sediments in fishing areas; and the study of urban soils in important cities of the country. ${ }^{17,18}$ The NAA was also used with $14 \mathrm{MeV}$ neutrons for the analysis of natural zeolites, grains, metals and superconductors, ${ }^{19}$ as well as in reactors, ${ }^{20}$ in order to determine their dependence on the neutron flow. What is known as the $k_{0}$ method has been used to develop neutron monitors ${ }^{21}$ to characterize zeolite deposits ${ }^{22}$ as well as in environmental studies for the sugar agroindustry.

Equipment based on interactions with substances that have different types of ionizing radiation (neutrons, gamma and beta radiations) have also been designed and developed for industrial applications in the following sectors: the nickel industry, ${ }^{23}$ the sugar industry ${ }^{24}$ and for the detection of weaknesses in welded joints in the steel and mechanical industry. ${ }^{25}$ It is also worth mentioning, as part of the national geological prospection program, the prospecting of uranium and thorium both in the form of deposits as well as in association with other minerals. ${ }^{26,27}$ Another of these applications based on the effects of ionizing radiation - in this case on biological minerals - is the creation of improved varieties of several economic crops. The method of radiationinduced mutagenesis together with biotechnological procedures has rendered effective results in different centers of the country. Some of the remarkable results obtained include the following: ${ }^{28,29,30}$ improved varieties of rice; the creation of five sugar cane mutants that are highly resistant against to the mosaic virus, and the beneficial application of this technique to garlic and wheat crops.

Nuclear physics applications in the public health sector have been notable and diverse. In fact, the joint work of nuclear physicists, radiation chemists, medical physicists, radiation biologists and the medical staff of all associated health institutions, have made possible important achievements in the production and use of radiopharmaceuticals in 
nuclear medicine in general, as well as in open source therapies and the application of closed source radiation therapy for safe and efficient treatments against cancer. In the linear accelerator installed at Hermanos Ameijeiras Hospital, several methods have been developed to calculate the absorbed dose of energy electron fields of between one and $21 \mathrm{MeV}$ by water and tissue layers. Similarly, by means of mathematical simulation, we managed to improve the quality of radiation therapy treatments using iodine needles and iridium wires. At the Medical and Surgical Research Center (CIMEQ), and with the purpose of maximizing the benefits and reducing side effects, the radioactive sources ${ }^{192} \mathrm{Ir},{ }^{125} \mathrm{I},{ }^{103} \mathrm{Pd} \mathrm{e}{ }^{169} \mathrm{Yb}$ used in brain brachytherapy were studied using Monte Carlo simulation.

In order to guarantee the accuracy of all the measurements taken, a Radio-Nuclide Metrology Laboratory was created at CENTIS (CENTIS-DMR) and a Secondary Dosimetry Calibration Laboratory (LSCD) set up at CPHR. The satisfactory results achieved by CENTIS-DMR and LSCD, together with the calibration (CMC) of the laboratory for pure gamma and beta emitters, led to their inclusion in Annex $C$ of the Database of the International Bureau of Weights and Measures (IBWM). ${ }^{31}$ As a result, the calibration certificates issued by both centers are also recognized by the national metrology laboratories of other countries. In addition, the Environmental Pollution Laboratory of the CPHR systematically offers its services in analyzing environmental samples, including samples of foodstuffs. The environmental radiological surveillance aimed at detecting and notifying any radiological anomaly that may originate either locally or abroad ${ }^{32}$ is guaranteed through a national network that is equipped to perform radio-nuclide measurements ${ }^{33}$ in real time and offer the required results in an expeditious way. Another service of an undoubted scientific and social value, offered by a multidisciplinary group of the same center, is based on the study of the biological effects of ionizing radiation. The studies by García, O, Medina, J. (et al.), ${ }^{34,35}$ using effective methods to estimate the radiological dosage received during accidents, allowed us to achieve positive results among the children and other persons who were affected by the Chernobyl accident. Between 1990 and 2012, the services offered by the national program created with the purpose of assisting the victims of this accident earned international recognition. Almost 25,000 persons from Ukraine, Belarus and Russia have benefitted. 


\section{The Development of Theoretical and Experimental Nuclear Physics}

The Cuban nuclear program included multiple training activities for research and professionals, which allowed nuclear physics research to take off in Cuba in pursuit of well-defined objectives; and also made it possible for us to cope with the scientific and technological challenges and materialize the expected results. This was possible thanks to the sustained efforts toward implementation and training the necessary technicians, specialists and scientists.

Scientific activity in the field of nuclear physics, from the organizational point of view, can be divided into two stages, table 3: the first stage, from 1980 to 1995; and the second stage, from 1996 to 2014. During the first stage the priority objectives of scientific programs were streamlined; the required conditions and infrastructure were created and the leading institutions and groups were further consolidated. The second stage started from the creation of AENTA in the mid-1990s, when economic restrictions and the tightening of the blockade compelled us to drop the nuclear power plant project in Juraguá in the year 2000. Nevertheless, based on the already existing infrastructure and potential, it was possible to reorient the technological innovation and scientific program - as described in Section 2 - towards the improvement of non-energy nuclear applications, other related applications and the already existing larger scale fundamental studies.

Table 3. Scientific activity in the field of nuclear physics

THE SCIENTIFIC ACTIVITY IN THE FIELD OF NUCLEAR PHYSICS

\section{First stage \\ 1980 - 1995}

Creation of the priority objectives of scientific programs, the required conditions and infrastructure. Consolidation of leading institutions and groups.

\section{Second stage}

$1996-2014$

Reorientation of science programs an innovation activities toward: improvement of non-energy nuclear applications; other related applications and existing fundamental studies of greater impact. 
These activities were based on the Nuclear Branch Program (1996-2005) and its continuation, and on the work of the dozens of national institutions involved in nuclear applications and the broad existing international cooperation.

Development of the first stage: ${ }^{36}$ Nuclear physics research developed in two directions: theoretical and experimental, as shown in table 4. The several theoretical research projects carried out focused on the collection of nuclear data, the study of nuclear fission and the physics of reactors, which led to an increasing domain of basic nuclear theory, plus the use of modern models for the calculation of neutron-induced nuclear reactions within a broad interval of nuclei and energies. It was also necessary to assimilate the physical-neutron and dynamic calculations of reactors; to delve deeper into thermo hydraulics and create a powerful national computing base at SEAN using EC-1066 systems. As to experimental research, part of it was carried out abroad, due to the lack of appropriate institutions at home. Nevertheless, the country was able to assimilate neutron activation, the reflection of thermal neutrons and other nuclear analytical techniques which, up to the present time, have been used particularly in the fields of medicine, agriculture and the mining and metallurgical industry. The domain of applied nuclear physics also required other competences and other associated technological devices in the following areas: materials science, nuclear electronics and instruments, computer sciences and the automation of experiments and processes, as well as in the manufacturing of limited series of equipment, parts and components of high added value.

Table 4. Development of the first stage

\begin{tabular}{|c|c|}
\hline \multicolumn{2}{|c|}{$\begin{array}{l}\text { FIRST STAGE } \\
\text { RESEARCH IN NUCLEAR PHYSICS }\end{array}$} \\
\hline THEORETICAL & EXPERIMENTAL \\
\hline $\begin{array}{l}\text { - nuclear data } \\
\text { - study of nuclear fission and the physics } \\
\text { of reactors } \\
\text { - basic nuclear theories } \\
\text { - modern models for the calculation of } \\
\text { neutron-induced nuclear reactions within } \\
\text { a broad interval of nuclei and energies } \\
\text { - physical-neutron and dynamic } \\
\text { calculations of reactors }\end{array}$ & $\begin{array}{l}\text { - neutron activation } \\
\text { - reflection of thermal neutrons } \\
\text { - other nuclear analytical techniques }\end{array}$ \\
\hline
\end{tabular}


To achieve all of the above, the Cuban nuclear program launched a sustained effort to educate and train the specialists that were required in the different stages. Among the multiple tasks implemented during the period 1980-1985, the creation of groups of young physicists and nuclear specialists of different profiles was remarkable, given its importance. They were offered every facility as well as solid training both in Cuba and abroad. CEADEN and ISCTN were the leading institutions of these activities within SEAN in the area of nuclear physics, and they were joined, in a gradual and differentiated way, by other centers. Table 5 includes a list of those institutions and their respective research areas. Some postgraduate programs were also introduced, which combined individual courses with participation in schools, workshops and scientific events. Thus, research projects turned out to be a substantial part of the bachelor of arts, master's and tutored $\mathrm{PhD}$ programs in nuclear physics.

Table 5. Main Institutions Associated with Nuclear Physics and their Respective Fields of Research

\begin{tabular}{|l|l|}
\hline Institution & Fields of Research \\
\hline CEADEN & $\begin{array}{l}\text { Solid-state technologies } \\
\text { (DRX,MR,MBE) } \\
\text { Experimental nuclear physics } \\
\text { Theoretical nuclear physics } \\
\text { Nuclear electronics }\end{array}$ \\
\hline ISCTN & $\begin{array}{l}\text { Nuclear analysis methods } \\
\text { Physics and technology of nuclear } \\
\text { reactors } \\
\text { Theoretical nuclear physics }\end{array}$ \\
\hline
\end{tabular}

Some of the relevant aspects not only for nuclear energy and other related specialties but also for basic research, all of which were in keeping with international experience and the requirements of the national scientific program, were the identification of the main lines of research as well as the prediction, collection and evaluation of neutron nuclear data from the structure of the nucleus, nuclear reactions and the nuclear fission process.

One landmark in the development of this specialty was the creation of a group of outstanding young scientists, whose results in theoretical research were crucial during the entire stage. As background information, it should be pointed out that between 1977 
and 1980, several theoretical projects were under way at the I.V. Kurchatov Atomic Energy Institute (IEA) in Moscow, using a microscopic approach to the layer models and studying the influence of input states on both the character of fluctuations at the crosssections of neutrons and on inelastic scattering in strongly deformed nuclei. ${ }^{37,38,39,40}$ The author, F. Castro Díaz-Balart ${ }^{1}$, who was in charge of this project and other research cited in this article (see endnote 37), followed the method used at the IEA - based on the school of academic L.D. Landau - to create a group of qualified researchers in Cuba, made up of outstanding young theoreticians who had been trained in different universities abroad. As long as they continued to gain experience in their respective specialties, they carried out state-of-the-art research in other related areas of knowledge. The group that embraced these types of research ultimately received recognition on an individual basis and most of its members were able to acquire a PhD and/or become senior researchers and full professors.

As can be seen throughout the evolution of these works ${ }^{41,42,43,44,45,46,47,48,49,50,51,52,53}$ most of them published by prestigious international publications - a deep knowledge about the physical processes that occur at nuclear facilities was sought through theoretical research. This focused on the study of the interaction among low-energy neutrons in the structural material used in nuclear technology, the development of theoretical methods to calculate the cross-section in the proximity of the threshold of reaction, and particularly the determination of the influence of an harmonism in the calculation of cross-sections and neutron angular distributions up to $5 \mathrm{MeV}$ of energy. Emphasis was also placed on the study of the state of a particle in spherical nuclei (A$60)$ and strongly deformed mid-weight nuclei (A-100); as well as the scattering of lowenergy particles and their applications in nuclear and medical physics. As part of the scientific program existing at that time, nuclear fission was also researched, given its association with the low-energy interaction mechanism for the reaction of excited neutrons with the nuclei of the actinides zone. ${ }^{54,55,56}$ The method that was developed, examining the deformation of the atomic nucleus, was used to calculate the fission cross-section of various and important components of the nuclear fuel cycle, taking into account the variation in its physical characteristics.

Parallel to this theoretical research, works aimed at the experimental collection of nuclear data in the same field of nuclear fission ${ }^{57,58,59,60,61,62,63}$ were begun. Benefiting

\footnotetext{
${ }^{1}$ The works published under the signature of J.R. Fernández Díaz were authored by him.
} 
from the possibilities offered by the IBR-30 reactor of the IUIN of Dubna, basic experimental research was carried out, such as the study of the radiation force function of several strongly deformed transition nuclei by means of the reaction $(n, ¥)$ in isolated resonance. The reaction $(n, p)$ by means of resonant neutrons was also studied. This allowed for comprehensive analysis of information about the structure of the wave function of the states of the compound nucleus for light nuclei in the $22<\mathrm{TO}<41$ zone. With the cooperation of the IAEA, works aimed at measuring cross-sections and angular distributions of neutron-induced reactions with an energy of $14 \mathrm{MeV}$ were also undertaken at INSTEC; an effective method ${ }^{64}$ was developed to determine the water content of natural zeolites through neutron reflection; ${ }^{65,66}$ various experimental techniques were assimilated, including activation, track-etching, coincidence techniques, nanosecond electronics and flashing liquids for pulse-form discrimination, among others.

Development of the second stage: The second stage began in 1996 (see table 6) and focused on theoretical nuclear research, the description of atomic nuclei as complex systems, particularly in relation to the study and the generally accepted description of excited nuclei and their mechanisms of nuclear relaxation. ${ }^{67,68,69,70,71,72}$ These are outlined as an exotic decline by means of a mechanism that emphasizes the geometric and symmetric properties of space, which, in turn, promoted the research of radioactive chains and their precursors. ${ }^{73,74,75,76,77,78,79,80,81,82}$ The impact of nuclear structure on heavy ion reactions near the Coulomb barrier was also studied - from the most symmetrical ways (fission-like) to the extremely asymmetric ones (proton emission), all of them within the framework of the same theoretical formalism and from a unified approach, which made it possible to create calculation codes that were published separately. Finally, the deformed nuclei zone was explored, from the perspective of the complexity of the surface of nuclear potential energy, in order to develop calculation tools capable of addressing up-to-date problems, such as the violation of parity in nuclear reactions. The results obtained were published in journals of international renown. ${ }^{83,84,85,86,87,88,89,90,91,92,93}$ 
Table 6. Development of the second stage

\begin{tabular}{|c|c|}
\hline \multicolumn{2}{|c|}{$\begin{array}{c}\text { SECOND STAGE } \\
\text { RESEARCH IN NUCLEAR PHYSICS }\end{array}$} \\
\hline THEORETICAL & EXPERIMENTAL \\
\hline $\begin{array}{l}\text { - atomic nuclei as complex systems } \\
\text { - excited nuclei } \\
\text { - mechanisms of nuclear relaxation } \\
\text { - The impact of the nuclear structure on heavy ion } \\
\text { reactions near the Coulomb barrier } \\
\text { - violation of parity in nuclear reactions near } \\
\text { deformed nuclei zone }\end{array}$ & $\begin{array}{l}\text { - development of nuclear methods of analysis in } \\
\text { several areas of interest } \\
\text { - collection of nuclear data for nuclear techniques } \\
\text { - characterization of zeolite and oil reserves } \\
\text { - environmental studies for the sugar agroindustry } \\
\text { - studies on the optimization of the medical } \\
\text { dosage to be administered } \\
\text { - research in the field of nuclear fission reactions } \\
\text { - works on the high energy physics linked to ALICE } \\
\text { experiment on (LHC) at CERN }\end{array}$ \\
\hline
\end{tabular}

When it comes to applied and experimental nuclear physics, projects associated with the development of nuclear methods of analysis, which are used in applications in the areas of medical physics, geological prospecting, agriculture, industry, radiological protection, dosimetry and the environment, continued to be pursued. They were also used to model and simulate nuclear and radioactive processes, and to collect nuclear data for nuclear techniques, among others. Such research was performed in the facilities of INSTEC and CEADEN, as well as in the laboratories of universities and research centers in different countries that were equipped with the appropriate apparatus. Some of the most important results obtained during this stage were the continuation lines described in Section 2, like those related to the modifications and additions introduced to the $\mathrm{k}_{0}$ method of analysis by neutron activation for the development of neutron monitors. This technique was used in the characterization of zeolite and oil reserves and in environmental studies for the sugar agroindustry; ${ }^{94,95,96,97,98,99,100}$ and in the studies on the optimization of the dosage to be administered in medical applications. ${ }^{101,102,103,104,105,106}$ Methods of quantification ${ }^{107,108}$ were also developed in different tests in the fields of nuclear medicine, radiological studies, and the modeling and simulation of experimental facilities. ${ }^{109,110,111,112,113,114,115}$ In addition, the level of heavy metal pollution in marine sediments and in urban soils of important cities in the country ${ }^{116,117,118}$ have also been studied. 
During the last decade some works were done in the field of nuclear fission reactions, in particular, the study of fission of light stable and weakly linked exotic nuclei; as well as in the comparative study of cross-sections of fission and total reaction, using weakly linked nuclei; and the study of the influence of the break-up process on the fission project.

Likewise, the impact of the nuclear structure of heavy ion reactions and the influence of break-up on the fission of the weakly linked nuclei were also researched. In addition, Xray spectrometry was also explored, since it was a new method for the study of fission suppression in the reaction ${ }^{9} \mathrm{Be}+{ }^{144} \mathrm{Sm}$, where the consistent analysis of elastic, inelastic and fission cross-sections was applied to the ${ }^{16} \mathrm{O}+{ }^{144-152} \mathrm{Sm}$ systems at energy levels below the Coulomb barrier, among others. Significant results have also been obtained in the development of a source of a Maxwell-Boltzmann neutron spectrum. ${ }^{119,120,121,122,123,124}$

In recent years, a group of young nuclear physicists has begun to work on the high energy physics linked to the ALICE experiment of the Large Hadron Collider (LHC) at CERN. The main results in this line of research have been obtained in the realignment of the SDD (Silicon Detecting Drift) detector, by applying the maximum drift time, the drift speed and the data obtained by detectors SPD and SSD. ${ }^{125}$ The ITS (Inner Tracking System) system of the ALICE experiment was characterized through a reconstruction of the traces produced by radiation beams. ${ }^{126,127,128,129}$ The load distributions as well as the momentum in the detectors used to identify loaded particles originating in protonproton $^{130,131,132,133,134}$ and $\mathrm{Pb}-\mathrm{Pb}$ collisions in the LHC have also been studied. 


\section{Conclusions}

The most valuable experience of the Cuban nuclear program has corroborated the fact that a small country with limited resources, in addition to the appropriate transfer of equipment and knowledge from industrialized nations, can only hope for the possibility of implementing a program to assimilate nuclear energy for peaceful purposes if, together with the necessary sustained effort, it is capable of creating the indispensable institutional infrastructure, training the necessary personnel and developing a coherent project of research and development of nuclear sciences and technologies. In order to face this challenge and materialize the expected results, it was crucial to continuously train and qualify the specialists, scientists, technicians and workers who were involved in this program. The effort made by the Cuban nuclear program in training nuclear specialists, both at home and abroad, has been significant. Taking into account the cooperation offered by the former USSR and the Eastern European countries as well as the specialists trained in Cuba since 1980, the number of graduates in nuclear specialties exceeds 2,220 - around 500 of them are nuclear physicists. If we also include the number of masters of sciences and PhDs, nuclear specialists account for the majority, together with the physicists who graduated from crash courses back in the 1970s.

Such an enterprise as the construction of the nuclear power plant in Juraguá, even though the project was abandoned, was also a cultural event that had an impact on many areas, particularly the level of technical training, experience and maturity achieved. There are hundreds of professionals, technicians and executives of several specialties who were trained for the nuclear energy program who have so far played a commendable role in different fields of science as well as in the national economy.

For the development of nuclear physics and the clear establishment of its objectives and priorities, training multidisciplinary groups of specialists in this field was important from the outset. They all contributed to the materialization of the envisaged scientific program. Equally relevant has been the permanent qualification of these groups, the organization and hosting high-level scientific seminars, workshops and institutes, as well as participation in international conferences and similar fora. Another fundamental factor has been the establishment of close relations between theoretical researchers and experimental researchers, who have been able to count on the valuable cooperation of our domestic specialists, the international nuclear research centers and IAEA. Nuclear 
physics, in addition to the multiple applied research and innovations described in this article, has provided greater visibility for Cuban science at the international level through hundreds of publications in renowned journals, patents obtained and the many awards granted by AENTA and the Cuban Academy of Sciences (ACC).

Nuclear techniques and radioactive sources are currently applied in many institutions from different sectors. One infrastructure comprises applications in the spheres of food and agriculture, sugar production, mining and industry in general. There is also an infrastructure for the study of water resources, the protection of marine and terrestrial environments, and a technical network for the safe, efficient use of radioactive resources, as well as for the detection of non-authorized radioactive and nuclear sources. Among the achievements attained as a result of the implementation of these applications, special reference should be made to those applications implemented in the public health system. The joint work by nuclear physicists, radiochemists, medical physicists, radiobiologists and personnel from other related health institutions made possible important achievements in the production and use of radiopharmaceuticals and nuclear medicine, open source therapy, closed source radiotherapy and the metrological security of measurements in every activity, including services to the biotechnology industry and to preclinical and clinical research on pharmaceuticals.

Twenty years ago, the SEAN system, which resulted from a reorganization of state institutions, merged with the former ACC and other small entities in order to found the Ministry of Science, Technology and the Environment, from which the Advanced Technologies and Nuclear Energy Agency (AENTA) emerged. AENTA took over from SEAN, aside from its logistic infrastructure and territorial delegations, its system of scientific and technical education institutions and the functions of systematically and professionally implementing the new policies entrusted to the nuclear program, as well as serving to support different branches of the economy that benefited from them. During this relatively short period of time, AENTA was able to preserve the comprehensiveness of the previous scientific, technological and productive system and safeguard its competent human resources, both of which were achieved after much effort and tenacity. This work shows that, at present, the agency has achieved a high level of maturity and has experienced and highly qualified personnel ready to face the new challenges posed by this technology, with maximum safety, for the benefit of the country. 
Nobody knows where the new advances in the fields of modern knowledge will lead us, but the intelligence, passion and courage for taking charge and conquering the unknown will always be necessary. New groups of mostly young scientists, engineers, workers and other future participants in this beautiful and unfinished work should be trained in an intensive and dedicated way, with the latest information about the newest advances of science and technology, keeping themselves acquainted with the development of nuclear energy in the world.

\section{Acknowledgements}

The balance of activities, as a result of research and innovations covering a 35-year period, obviously can neither include nor evaluate all the work done at every moment. Therefore, based on the assessments made by different specialists, only the main works and those of greater relevance have been included. It is impossible to list other professionals from the AENTA centers who contributed information and their experience, but it is impossible not to mention those who contributed to this work: engineers Aniuska Betancourt, Marta Contreras, Jorge Cruz and A. Hernández, as well as Professor Hugo Pérez and other nuclear physicist colleagues, like Drs. Oscar Rodríguez, Iván Padrón, Oscar Díaz, Gladys López and Luis Desdín. 


\section{Notes}

${ }^{1}$ Pruna Goodgall, P. M., 2011:Ciencia y Científicos en Cuba Colonial, Havana, Editorial Academia de Ciencias de Cuba.

${ }^{2}$ Castro Díaz-Balart, F. 1990. Energía nuclear y desarrollo. La Habana: Editorial CienciasSociales, 2nd edition 1991, porColihue, Argentina.

${ }^{3}$ Pérez Rojas, H., D. Stolik, J. Fuentes, et al., 1976. "Estado actual de las Ciencias Físicas en Cuba." In Las Ciencias Básicas: Examen preliminar de su situación actual en Cuba y a nivel mundial. pp. 45-46.

${ }^{4}$ Castro Ruz, F. (1960) Intervención ante la Sociedad Espeleológica de Cuba el 15 de enero de 1960. www.cuba.cu/gobierno/discursos/1960

${ }^{5}$ Academia de Ciencias de Cuba. 1979. Memoria 1969-1979, Instituto de Investigaciones Nucleares. La Habana.

${ }^{6}$ Cabal, C. 2014. "Physics at the university of Oriente" in The history of Physics in Cuba, ed. by. A. Barraca, J. Renn, H. Wendt. Springer, pp. 247-260.

${ }^{7}$ Castro Díaz-Balart, F. 2010. Intervención en el panel por el 30 Aniversario de la creación de la Comisión de Energía Atómica de Cuba y la SEAN, en los marcos de los 50 años del Día de la Ciencia.Salón Baire, Capitolio Nacional, Havana.

${ }^{8}$ Blix, H. 1987. Entrevista a Hans Blix: "Cuba posee un programa nuclear bien estructurado". Nucleus 3, pp. 36-37.

${ }^{9}$ Castro Díaz-Balart, F. 2011. Nuclear Energy: Environmental danger or solution for the $21^{\text {st }}$ Century. Ed. Lagos S. A., Monterrey, México. Previous editions in several countries and languages.

${ }^{10}$ Castro Díaz-Balart, F. 1985. Nuclear Energy in Cuba in collaboration with Comecon Countries, ed. Comecon, Moscow, Russia.

${ }^{11}$ Contribution to the United Nations Conference for the Promotion of International Co-operation in the Peaceful Uses of Nuclear, Geneva, Switzerland. A/CONF.108/NPR/Add.1 March 1987. Energy.

${ }^{12}$ Alonso Mederos, Danilo. 1989. "La formación del personal calificado: un factor imprescindible." Nucleus 7, pp. 59-62.

${ }^{13}$ Baracca, A., V. Fajer and C. Rodríguez. 2006. "A Look at Physics in Cuba Physics Today" 59 (9): 42-48; The History of Physics in Cuba, ed. by. A. Barraca, J. Renn, H. Wendt. Springer.

${ }^{14}$ Memorias de la I, II and III Escuelas para los problemas actuales de las ciencias nucleares, editorial CIEN, 1980, 1985 and 1988.

${ }^{15}$ Díaz García, A. 2006. "Influencia de las aplicaciones nucleares en la sociedad contemporánea." Rev. Nucleus 40, pp. 6-14.

${ }^{16}$ Pérez, G. et al. 1993."Determination of naturally radioactive elements in construction materials by means of gamma-spectroscopy, track registration techniques and neutron activation analysis."J. of Radioanal and NuclChem 176, 4, pp. 315-323.

${ }^{17}$ Alonso, C. et al. 2006."Tendencia histórica de la contaminación por metales pesados en sedimentos de la bahía de Cienfuegos, definida con la geo cronología del Pb-210 y Cs-137." Nucleus 39, pp. 20-26.

${ }^{18}$ Díaz, O. et al. 2008."Análisis ambiental por activación neutrónica de sedimentos de la bahía de La Habana."Nucleus 44, pp. 15-23.

${ }^{19}$ Hernández A. 1985. Utilización del microtrón para el análisis por activación de rocas y substancia meteoritica. Doctoral theses for the degree of $\mathrm{PhD}$ in physics and mathematics. IUIN, Dubna, USSR.

${ }^{20}$ Díaz Rizo, O. et al. 1997."A reactor power dependence for the $\mathrm{k}_{0}$ neutron flux parameters."J Radioanal NuclChem, 221/2, pp. 241-244.

${ }^{21}$ Díaz Rizo, O., ÁlvarezPellón, I., Herrera Peraza, E.F., et al. 1997. "HAV-1: A Multipurporse Monitor for Reactor Epithermal Neutron Flux Characterization."J Radioanal NuclChem 220/1, pp. 99-02. 
${ }^{22}$ Díaz Rizo O., Herrera Peraza, E.F. 1997. "Multi-elemental characterization of Cuban natural zeolites,"J RadioanalNuc/Chem221/2, pp. 255-258.

${ }^{23}$ Herrera, V., et al. 2003."Spinel-type iron and chromium oxides in residuals of Nickel industry." Memorias de VII Taller de Tecnologías y materiales para la industria del sector Metánica, CD-Rom, ISSN-1607-6281.

${ }^{24}$ Griffith, J. 1997. Actual status and perspectives of radiotracer applications in the cuban Techniques in Agriculture, Industry, Health and Environment. Havana. Section Industry.

${ }^{25}$ Domínguez, A. et al. 1992. Relación entre la sensibilización del acero08X18M10T. Informe final del Proyecto Nacional "Equipos nucleónicos de medición de parámetros industriales para el control de calidad y la eficiencia en la Industria Azucarera."

${ }^{26}$ Góngora, L.E. et al. 1995."Pronóstico de áreas favorables para la prospección de uranio en el macizo metamórfico de la Isla de la Juventud." Nucleus 19, pp.19-21.

${ }^{27}$ Padilla, R., Capote G. 1995. "Estudio del efecto matriz para determinar uranio en muestras minerales mediante el método gamma espectrométrico." Nucleus No. 19, pp. 10-12.

${ }^{28}$ González, L.M., Ramírez, R. 2002. "La radioinducción de mutaciones en las plantas y sus beneficios para la agricultura." Nucleus 31, pp.3-7.

${ }^{29} \mathrm{González,} \mathrm{L.,} \mathrm{Iglesias,} \mathrm{L.} \mathrm{1998.} \mathrm{"Análisis} \mathrm{de} \mathrm{la} \mathrm{variabilidad} \mathrm{isoenzimática} \mathrm{en} \mathrm{mutantes} \mathrm{de} \mathrm{arroz}$ obtenidos por radioinducción de mutaciones." Nucleus 25, pp.18-23.

${ }^{30}$ Pérez, S. et al. 1997."Obtención de nuevas variedades de trigo por mutaciones inducidas." Proceedings of International Symposium on Nuclear and Related Techniques in agriculture, Industry, Health and Environment. Havana, pp. 31-33.

${ }^{31}$ Key Comparison Database of the Bureau International des Poidset Mesures (BIPM), consulted: 2011 [online database]. <http: //kcdb.bipm.org/>.

${ }^{32}$ Oropesa, P. et al. 2011."Patronescubanos de la medición de los radionúclidos." 8 Simposio Internacional Metrología 2011; Havana.

${ }^{33}$ Domínguez, O. et al. 2005."Automatización del monitoreo en tiempo real de la tasa de dosis absorbida en aire debido a la radiación gamma ambiental en Cuba." Nucleus 37, pp. 20-24.

${ }^{34}$ García, O. et al. 2005."Introducción y desarrollo de la dosimetría biológica en Cuba." Nucleus 37 , pp. 49-53.

${ }^{35}$ García, O., Medina, J. 2005. "Quince años del programa cubano con niños de territorios afectados por el accidente de Chernobil." Nucleus 37, pp. 39-43.

${ }^{36}$ Castro Díaz-Balart, F. 1989. "La física nuclear y la evaluación de datos nucleares en Cuba," Nucleus 7, pp. 15-23.

${ }^{37}$ Fernández Díaz, J. R. 1978. "Fluktuatsii Neytronno dispersionnykh secheniy i vkhodnykh sostoyaniy" The Fluctuations of the neutronic dispersion's section and the doorway states," Report IAE - 2974, Moscow, 32 pages.

${ }^{38}$ Fernández Díaz, J. R., Sirotkin, V. K. 1978. "Microscopic approach to neutron total crosssection fluctuation." Nucl. Phys. A 312, p. 17.

${ }^{39}$ Fernández Díaz, J. R., Sirotkin, V.K. 1980. On the energy dependence of the inelastic crosssection in the presence of doorway states. II Nuovo Cimento 56, p. 21

${ }^{40}$ Fernández Díaz, J. R., Sirotkin, V.K. 1980. "A dynamical approach of the statistical theory of the nuclear reactions" Scientific-technique Report No. 126, Academy of Sciences of Cuba, 25 pages.

${ }^{41}$ Fernández Díaz, J.R., 1982. Revista Ciencias Químicas 13 p. 145.

${ }^{42}$ Fernández Díaz, J.R., Cabezas Solórzano, R. 1982. Proc. Int. Conf. on Nuclear Data for Science and Technology. Antwerp, Belgium p. 582.

${ }^{43}$ Fernández Díaz, J.R., Cabezas Solórzano, R. 1983. "Study for the low-energy neutron inelastic scattering in deformed transitional nuclei: ${ }^{186}$ W." Journal of Phys. G 9, pp. 11151123.

${ }^{44}$ Cabezas Solórzano, R, LópezTuero, J. L. 1987. Nucleus 3, p. 8.

${ }^{45}$ Fernández Díaz, J.R., Cabezas Solórzano, R. 1986. Proc. Int. Cont. on Nuclear Physics, Harrogate, United Kingdom VI, p. 421.

${ }^{46}$ Ivanova, S.P., Cabezas Solórzano, R., Korzh, J. A. et al. 1987. YadFiz. 46, p. 479. 
${ }^{47}$ Ivanova, S.P., Cabezas Solórzano, R., Pedrosa Martínez, R., Ponomariov, V. Yu. 1988. YadFiz. 48, p. 703.

${ }^{48}$ Jolos, R.V., Ivanova, S.P., Pedrosa Martínez, R, Preprint IUIN,Dubna P4-88-174.

${ }^{49}$ Fernández Díaz, J.R. 1983. Revista Cubana de Física 3 p. 7.

${ }^{50}$ Fernández Díaz, J.R, Cabezas Solórzano, R, López Méndez, R. 1984. Revista Cubana de Física 4, p. 49.

${ }^{51}$ Fernández Díaz, J.R, Cabezas Solórzano, R, López Méndez, R. 1985. YadFyz.41 p. 1508.

${ }^{52}$ Fernandez Díaz. 1985. International Conference of Nuclear Data for Basic and Applied Research. Santa Fé, USA.

${ }^{53}$ Capote Noy, R., López Méndez, R, Osorio Fernández, V., Herrera Peraza, E. 1987. Procc. Int. Symp. On Nucl. Reactions, Gaussig, GDR, ZfK-646 (1988) 48.

${ }^{54}$ García Velazco, F., Guzmán Martínez, F., Mora Alfonso, M., Rodríguez Hoyos, O. 1988 .Int. Symp. On Nucl. Assion, Gaussig, GDR.

${ }^{55}$ Egorov, S., V.A. Rubchenya, F. García and O. Rodriguez. 1992. "Combined method of deformed nuclei level density calculations." INDC -006/E, IAEA.

${ }^{56}$ García, F., O. Rodríguez, E. Garrote and E. López. 1993. "A Combined Method in fission cross section calculations." Journal of Physics G 19, p.2157-2166.

${ }^{57}$ Desdín, L., S. Szegedi, J. Csikai. 1989. Measurement of the fission cross-section ratio for237Np/235U around $14 \mathrm{MeV}$ neutron energies. Acta Physica Hungarica 65 (2-3), pp. $271-$ 275.

${ }^{58}$ González Mateu, D. 1989. Nucleus 6, p. 10.

${ }^{59}$ Bechbarzh, F., Montero Cabrera, M.E., Rigol Pérez, J.M., Telezhnikov, S.A., Phuong Hiep, H. 1987.YadFiz. 45, p. 3.

${ }^{60}$ Bechbarzh, F., Montero Cabrera, M.E., Pospishil, S., Telezhnikov, S.A. 1986. YadFiz. 44, p. 3.

${ }^{61}$ Gledenov, Yu. M., Kvitek. J., Marinova, S., Popov Yu., P., Rigol Pérez, J.M., Salastki, V. I. 1982. "The investigation of the reaction22 $\mathrm{Na}(\mathrm{n}, \mathrm{p}) 22 \mathrm{Ne}$ for a neutron energy to 1,000 eV." Zeitschrift für Physik A Atoms and Nuclei 308 (1), pp. 57-61.

${ }^{62}$ Antonov, A., Viesna, V.A., Gledanov, Yu. M., Zvarova, T. S., Lovashov, B. M., Oruniek, I.S., Popov, Yu. P., Rigol Pérez, J. M., Smotritskii, L. M., Shulguina, E.V.1988 YadFiz. 48, p. 305.

${ }^{63}$ Ortlepp, H.G., Fromm, W.D., RomagueraFernández, A., Heidel, K., Strekalovsky, O. V. 1988. Symp. on Heavy lons, Dresden, RDA.

${ }^{64}$ Proyecto de AsistenciaTécnica del OIEACUB/1/005.

${ }^{65}$ Gandarias Cruz. D., Medina Acosta, M.A., INDC (CUBA)-001/G, p. 13.

${ }^{66}$ García V.F., Rodriguez H.O., Garrote P.E. and Rubchenya V.A. 1995. "DENCOM: Code for level density calculation of deformed nuclei using a combined method." Computer Physics Communication 86, p. 129.

${ }^{67}$ Arruda-Neto, J., M. Yonoema, J. Díaz, F. García, M. Reigota, V. Likhachev, F. Guzmán, O. Rodríguez, J. Mesa. 1997. "Electrofission of Pu 239 in the energy range 7-12." MeV. Phys. Rev C. 55 (5), p. 2471.

${ }^{68}$ Gonçalves, M., S. Duarte, F. García and O . Rodríguez. 1997. "PRESCOLD code: Calculation of the half life for alpha decay, cluster radioactivity and cold fission process." Comp. Phys. Comm. 107.

${ }^{69}$ Sotolongo, O., F. Guzmán, O. Rodríguez and F. García. 1997. "Scaling laws in mass distribution in the universe." Nucleus 22, p.14.

${ }^{70}$ Duarte, S., O. Rodríguez, O. Tavares, M. Gonçalves, F. García, and F. Guzmán. 1998. "Cold fission yield calculation for varying and constant mass asymmetries." Phys. Rev. C. 57(5), 2516.

${ }^{71}$ García, F., E. Garrote, F. Guzmán y O. Rodríguez.1998. "Análisis sistemático de las secciones eficaces de fisión de los isótopos del uranium y del plutonium." Rev. Cub. Física 15(1), p. 51.

${ }^{72}$ Arruda-Neto, J., S. Simionatto, V.Likhachev, F. Garcia, J. Mesa, A Deppman, O. Rodriguez and F.Guzman. 1998. "Photoneutron Multiplicities of preactinides nuclei at energies above the Pion threshold." Nuclear Physics A 638, p. 701.

${ }^{73}$ Tavares, O., S.Duarte, O. Rodríguez, F. Guzmán, M. Gonçalves and F. García. 1998. 
"Effective liquid drop description for alpha decay of atomic nuclei." CBPF-NF-044(1998), Journal of Physics G: Nuclei and Particle 24, p. 1757.

${ }^{74}$ Rodríguez, O., F.Guzmán, O.Tavares, S. Duarte, F.García and M. Gonçalves. 1998. "New valley of cold fission and cluster radioactivity processes for nuclei far from the $\beta$-stability line." Phys. Rev. C 59, p. 253.

${ }^{75}$ García, F., O. Rodríguez, J. Mesa, J. Arruda-Neto, V. Likhachev, E. Garrote and F. Guzmán. 1999. "BARRIER Code: Calculations of fission barriers." Comp. Phys. Comm. 120, p. 57.

${ }^{76}$ Díaz, A., F. Guzman and O. Rodríguez 1999. "Cold events in thermal-neutron-induced fission of heavy nuclei." European Phys. J.A 4, p. 51.

${ }^{77}$ Rodríguez, O., F. García, H. Dias, J. Arruda, E. Garrote and F. Guzmán. 2001. "LINDEN: Code for level densities calculations using the Lipkin-Nogami method"'. Comp. Phys. Comm. 137, p. 405.

${ }^{78}$ Arruda-Neto, J.D.T., et. al. 1997. Electrofission of 239Pu in the energy range $7-12 \mathrm{MeV}$. Physical Review. C, Nuclear Physics 55, p. 2471-2481.

${ }^{79}$ García, F., O. Rodríguez, M. Gonçalves, S.B. Duarte, O.Tavares and F. Guzmán. J. 2000. "Alpha decay and nuclear deformation: The case for favoured alpha transitions of even-even emitters." CBPF-NF-011/2000, F. García, O. Rodríguez, M. Gonçalves, S.B. Duarte, O. Tavares and F. Guzmán.J. Phys. G: Nuclei and Particle Physics 26(6), p. 755.

${ }^{80}$ García, F., O. Rodríguez, F. Guzmán, H. Días, J. Arruda-Neto and M.S. Hussein. 1999. "Particle-hole level densities in deformed nuclei." Phys. Rev. C 60, 064311.

${ }^{81}$ Guzmán, F., M. Gonçalves, O. Tavares, S. Duarte, F. García and O.Rodríguez. 1999. "Proton radioactivity from proton-rich nuclei." Phys. Rev. C 59(5), 2339.

${ }^{82}$ Geraldo, L., R. Semmler, O. Glez, J. Mesa, J. Arruda, F. García and O. Rodríguez. 2000. "Photofission Cross Sections for 237Np in the energy interval from 5.27 to $10.83 \mathrm{MeV}$." Nucl. Science and Engineering 136. p. 357.

${ }^{83}$ Dimarco, A., S. Duarte, O. Tavares, F. García, O. Rodríguez and F. Guzmán. 2000. "Effect of nuclear deformation on the alpha-decay half-life of even-even alpha emitters." CBPF-NF018/2000, Int. Journal of Mod Phys. Rev E 9(3), p. 205.

${ }^{84}$ Duarte, S.B., O. Tavares, F. Guzmán, O. Rodríguez, F. Garcíaand M. Gonçalves. 2002. "From proton emission to cold fission: A unified theory of spontaneous nuclear decay processes." Atom. Data and Nucl. Data Table 80.

${ }^{85}$ Likhachev, V., J. Arruda, O. Rodríguez, A. Buki, F. García, I. Evseev, M. Martins, J. Mesa, H. Schelin and V. Shostak. 2001. "Contribution of quasielastic scattering to the inclusive electrofission cross section of uranium at E0=100-250." MeV. Bras. J. of Phys.

${ }^{86}$ Likhachev, V., J. Mesa, B. Carlson, A. Deppman, M. Hussein, V. Nesterenko, O. Rodríguez, and F. Garcia 2002. "Quasifree electrofission of uranium 238." Phys. Rev. C. 65(4), P. 044611.

${ }^{87}$ Deppman, A., O. Tavares, S. Duarte, J. Arruda, V. Likhachev, O. Rodriguez, J. Mesa, and M. Goncalves. 2001. "Photofissility of actinide nuclei at intermediate energies." Phys. Rev. Letters 87.

${ }^{88}$ Arruda, J., J. Mesa, O. Rodriguez, M. Filadelfo, V. Likhachev, L. Geraldo, R. Semmler, A. Deppman, F. García and F. Guzmán. 2001. "The Role of 237Np Transitional Levels in its (g,f) Cross Section Structures near the Threshold." Phys. Rev. Letters.

${ }^{89}$ Duarte, S., O. Tavares, F. Guzmán, O. Rodríguez, F. Garcíaand M. Gonçalves. 2001. "Superheavy elements formation in cold fussion reactions." Phys. Rev. C.

${ }^{90}$ Castro Smirnov, F., O. Rodríguez-Hoyos, F. Guzmán, V. Comas Lijashev. 2005. "Fusion cross sections in the superheavy elements formation process." Nucleus, pp. 42-48.

${ }^{91}$ Comas Lijashev, V., O. Rodríguez-Hoyo, F. Guzmán, F. Castro Smirnov. 2005. "Two proton emission in the effective liquid drop model(ELDM)." Nucleus, pp. 5-12.

${ }^{92}$ Duarte, S., O. Tavares, M. Gonçalves, O. Rodríguez, F. Guzmán and F. García. 2004. "Halflife predictions for decay modes of superheavy nuclei." Journal of Physics G-Nuclear and Particle Physics 30(10), pp. 1487-1494. 
${ }^{93}$ Arruda-Neto, J.D.T., J. Mesa, F. García, O. Rodríguez, L.P. Geraldo, C. García, T.E. Rodrígues, Shtejer, K., R. Semmler, F. Guzmán. 2006. "The Role of Transitional Levels in 237Np ( g, f ) - perspectives to study highly deformed systems," Phys. Rev C 74, 034324.

${ }^{94}$ DíazRizo, O., M.V. Manso Guevara, E.F. Herrera Peraza et al. 1997. "A reactor power dependence for the $\mathrm{k}_{0}$ neutron flux parameters." J RadioanalNuc/Chem 221(2), pp. 241-244.

${ }^{95}$ Herrera E, O. DíazRizo, M.V. Manso, et al.1999. "Development and implementation of the $\mathrm{k}_{0^{-}}$ standardization method. Part I." J RadioanalNuclChem 240(2), pp.437-443.

${ }^{96}$ Díaz Rizo, O., O. Herrera, M.V. Manso, et al. 1999. "Development and implementation of the $\mathrm{k}_{0}$-standardization method. Part II." J RadioanalNuc/Chem 240(2), pp. 445-450.

${ }^{97}$ Díaz Rizo O., I. Álvarez Pellón, E.F. Herrera Peraza, et al. 1997. "HAV-1: A Multipurporse Monitor for Reactor Epithermal Neutron Flux Characterization." J RadioanalNuclChem 220(1), pp. 99-102.

${ }^{98}$ Díaz Rizo, O., A.M. Graciano, et al. 2005. "Epithermal neutron flux characterization of the IEAR1 research reactor, Sao Paulo, Brazil, for use in INAA." JJ RadioanalNuclChem 266(1), pp.153-157.

${ }^{99}$ Montero, M. E., E. Herrera, O. Cabrera, et al. 1997. "Elementos trazas de las rocas reservorios de petróleo en los yacimientos de Habana Matanzas." Nucleus 23, pp. 8-13.

${ }^{100}$ DíazRizo, O., y J. Griffith. 1996. "Soil-plant relation in sugar cane by INAA." J RadioanalNuclChem 213 (5), pp. 377-384.

${ }^{101}$ Gelen, A., N. López, O. Díaz Rizo, et al. 2005. "Gamma Activation Analysis of sediments at Havana bay (Cuba)." J RadioanalNuclChem 266 (3), pp. 485-490.

${ }^{102}$ Díaz Rizo, O., A. Gelen, A.M.G. Figuereido, et al. 2012. "REE enrichment in Havana bay surface sediments using INAA." J RadioanalNuc/Chem 292, pp. 81-84.

${ }^{103}$ Pérez Díaz, M., O. Díaz Rizo, R. Dopico, et al. 2002. "Administered Activity Optimization in Patients Studied by Equilibrium Gated Radionuclide Ventriculography Using Pyrophosphate and Tc-99m." NuclMedCommun 23, pp. 347-353.

${ }^{104}$ Pérez, M, E. Aparicio, O. Díaz Rizo, et al. 2003. "Administered Activity Optimization in 99mTcMAG3 Renography for Adults." J Nucl. MedTechnol 31, pp. 216-221.

${ }^{105}$ Pérez Díaz, M., O. Díaz Rizo. 2006. "Métodos de optimización de la actividad a administrar al paciente en estudios de Medicina Nuclear." RevEspFís Médica 6(1), pp. 32-36.

${ }^{106}$ Pérez Díaz, M., O. Díaz Rizo, E. Aparicio, et al. 2007. "Activity Optimization in HMPAO 99mTc Brain SPECT." Health Phys. 93 (1), S23.

${ }^{107}$ Sánchez, C., O. Díaz, M. Rodríguez, R. Rodríguez, R. Águila. 2002. "Mejoramiento de la cuantificación relativa del flujo sanguíneo cerebral con la tecnología médico-nuclear disponible en el país." Nucleus 31, pp. 8-17.

${ }^{108}$ Sánchez, C., R. Puchal, O. Díaz Rizo, A. Águila. 2003. "Problemas que afectan la cuantificación en SPECT." RevEspFís Médica 4(1), pp. 31-41.

${ }^{109}$ Sánchez Catases, C. A., O. Díaz Rizo, et al. 2003. "Métodos para el mejoramiento de la cuantificación relativa del flujo sanguíneo cerebral mediante SPECT." Alasbimn Journal $6(22)$.

${ }^{110}$ Reyes, H., N. López-Pino, O. Díaz Rizo, et al. 2009. Environmental Radioactivity Study in Surface Sediments of Guacanayabo Gulf (Cuba). AIP Conf. Proc.1139, pp.156-157.

${ }^{111}$ Díaz Rizo, O., A. Gelen Rudnikas, J.O. Arado López, et al. 2013. "Radioactivity levels and radiation hazard of healing mud from San Diego River," Cuba. J RadioanalNuc/Chem 295, pp. 1293-1297.

${ }^{112}$ Gelen, A., O. Díaz, M.J. Simón et al. 2003. "210 $\mathrm{Pb}$ of sediments from Havana Bay.” J RadioanalNuc/Chem 256(3), pp. 561-564.

${ }^{113}$ Zerquera, J.T.; M. Prendes, I.M. Fernández, et al. 2006. "Studies on Internal Exposure Doses Received by the Cuban Population due to the Intake of Radionuclides from the Environmental Sources." RadiatProtDosim 121(2), pp.168-174.

${ }^{114}$ Zerquera, J.T.; M. Prendes, O. Díaz Rizo. 2007. "Distribution of doses received by Cuban population due to environmental sources of radioactivity." RadiatProtDosim 123(1), pp.118121. 
${ }^{115}$ Casanova, O., N. López, A. Gelen et al. 2004. "Shielding analysis of the Microtron MT- 25 bunker using the MCNP-4C Code and NCRP Report 51." RadiatProtDosim 109(3), pp. 189195.

${ }^{116}$ Heredia Carmona, J., O. Díaz Rizo. 2009. "Experimental and Monte Carlo determination of mass absorption coefficients for ${ }^{90} \mathrm{Sr} /{ }^{90} \mathrm{Y}$ beta particles in organic compounds." Nucleus 45 , pp. 26-31.

${ }^{117}$ Díaz Rizo, O., S. Olivares Reumont, J. Viguri Fuente, et al. 2010. "Copper, Zinc and Lead Enrichments in Sediments from Guacanayabo Gulf, Cuba, and its Bioaccumulation in Oysters, Crassostrearhizophorae." Bull EnvironContamToxicol 84(1), pp. 136-140.

${ }^{118}$ Díaz Rizo, O., D. FonticiellaMorell, J.O. Arado López, et al. 2013. "Spatial distribution and contamination assessment of heavy metals in urban topsoils from Las Tunas city, Cuba." Bull EnvironContamToxicol 91, pp. 29-35.

${ }^{119}$ Silveira Gomes, P., I.Padrón, et al. 2005. "Effect of the breakup on the fusion end elastic scattering of weakly bound projectiles on ${ }^{64}$ Z." Physical Review C: Nuclear Physics 71, p. 034608.

${ }^{120}$ Arazi, I. Padrón, et al. 2005. "Fusion, reaction and break-up cross sections of ${ }^{9} \mathrm{Be}$ on a light mass target." Physical Review C: Nuclear Physics 71, p. 027602.

${ }^{121}$ Silveira Gomes, P., I. Padrón, et al. 2005. "Uncertainties in the comparison of fusion and reaction cross section of different system involving weakly bound nuclei." Physical Review C: Nuclear Physics 71, p. 017602.

${ }^{122}$ Silveira Gomes, P., I. Padrón, J. Lubian. 2007. "Fusion of weakly bound nucleo." Journal of Radioanalytical and Nuclear Chemistry 272(2), pp. 215-218.

${ }^{123}$ García, V.F., I. Padrón, et al. 2007. "Threshold anomaly in the elastic scattering of $6 \mathrm{He}$ on ${ }^{209}$ Bi." Physical Review C: Nuclear Physics. 76, p. 067603.

${ }^{124}$ García, A., I. Padrón, P. Silveira Gomes, et al. 2008. "Limitation of double holding potentials to simulate the polarization in reactions involving halo nuclei." Nuclear Physics A: Nuclear and Hadronic Physics 806, pp. 146-155.

${ }^{125}$ Alessandro, B. et al. 2010. "Operation and calibration of the Silicon Drift Detectors of the ALICE experiment during the 2008 cosmic ray data taking period: The ALICE-SDD Group." $J$ Instrument 5 P04004.

${ }^{126}$ Allen J, et al. 2010. "Performance of prototypes for the ALICE electromagnetic calorimeter." NuclnstrumMethPhys ResA 615, pp. 6-13.

${ }^{127}$ Aamodt, K., et al. 2010. "Alignment of the ALICE Inner Tracking System with cosmic-ray tracks." J Instrument 5 P03003.

${ }^{128}$ Aamodt, K., et al. 2010. "Midrapidity Antiproton-to-Proton Ratio in ppCollisons at 0:9 and 7 TeV Measured by the ALICE Experiment." Phys Rev Lett 105072002.

${ }^{129}$ Aamodt, K., et al. 2010. "Production of pions, kaons and protons in pp collisions $\sqrt{ } \mathbf{s}=900 \mathrm{GeV}$ with ALICE at the LHC." EurPhys J. C 71(6), p. 1655.

${ }^{130}$ Casanova Díaz, A., G. Conesa Balbastre, C. García Trápaga. 2011. "High pTy and jets predictions with PYTHIA and HERWIG in p-p collisions at $\sqrt{ } s=14 \mathrm{TeV}$ at LHC."Nucleus No. 50 , pp. 12-17.

${ }^{131} \mathrm{Abalev}, \mathrm{B}$., et al. 2012. "Neutral pion and $\eta$ meson production in proton-proton collisions at $\sqrt{ } \mathrm{s}$ $=0.9 \mathrm{TeV}$ and 7 TeV." PhysLett B 717, pp. 162-172.

${ }^{132}$ Aamodt, K., et al. 2012. "Particle-yield modification in jet-like azimuthal di-hadron correlations in $\mathrm{Pb}-\mathrm{Pb}$ collisions at $\sqrt{\mathrm{sNN}}=2.76 \mathrm{TeV}$." Phys Rev Lett 108, 092301.

${ }^{133} \mathrm{Abalev}$ B., et al. 2012. "Suppression of high transverse momentum prompt $D$ mesons in central $\mathrm{Pb}-\mathrm{Pb}$ collisions at $\sqrt{\mathrm{sNN}}=2.76 \mathrm{TeV}$." J High EnerPhys 9, p. 112. 



\section{MAX-PLANCK-INSTITUT FÜR WISSENSCHAFTSGESCHICHTE}

\section{Max Planck Institute for the History of Science}

Preprints since 2013 (a full list can be found at our website)

437 Jürgen Renn Schrödinger and the Genesis of Wave Mechanics

438 Pietro Daniel Omodeo L'iter europeo del matematico e medico scozzese Duncan Liddel

439 Irina Tupikova \& Klaus Geus The Circumference of the Earth and Ptolemy's World Map

440 Pietro Daniel Omodeo und Jürgen Renn Das Prinzip Kontingenz in der Naturwissenschaft der Renaissance

441 Horst Kant und Jürgen Renn Eine utopische Episode - Carl Friedrich von Weizsäcker in den Netzwerken der Max-Planck-Gesellschaft

442 William G. Boltz and Matthias Schemmel The Language of 'Knowledge' and 'Space' in the Later Mohist Canon (TOPOI - Towards a Historical Epistemology of Space)

443 Stefano Bordoni Looking for a Rational Thermodynamics in the late XIX century

444 Sonja Brentjes and Jürgen Renn The Arabic Transmission of Knowledge on the Balance

445 Horst Nowacki Archimedes and Ship Design

446 Matthias Schemmel Elements of a Historical Epistemology of Space (TOPOI - Towards a Historical Epistemology of Space]

447 Martin Thiering and Wulf Schiefenhövel Spatial Concepts in Non-Literate Societies: Language and Practice in Eipo and Dene Chipewyan (TOPOI - Towards a Historical Epistemology of Space]

448 Jürgen Renn Einstein as a Missionary of Science

449 Hubert Laitko Der Ambivalenzbegriff in Carl Friedrich von Weizsäckers Starnberger Institutskonzept

450 Stefano Bordoni When Historiography met Epistemology. Duhem's early philosophy of science in context

451 Renate Wahsner Tausch - Allgemeines - Ontologie oder Das Auseinanderlegen des Konkreten und seine Aufhebung

452 Jens Høyrup Algebra in Cuneiform. Introduction to an Old Babylonian Geometrical Technique

453 Horst Nowacki Zur Vorgeschichte des Schiffbauversuchswesens

454 Klaus Geus and Mark Geller (eds.) Esoteric Knowledge in Antiquity (TOPOI - Dahlem Seminar for the History of Ancient Sciences Vol. II]

455 Carola Sachse Grundlagenforschung. Zur Historisierung eines wissenschaftspolitischen Ordnungsprinzips am Beispiel der Max-Planck-Gesellschaft (1945-1970)

456 David E. Rowe and Robert Schulmann General Relativity in the Context of Weimar Culture

457 F. Jamil Ragep From Tūn to Turun: The Twists and Turns of the Ṭūsi-Couple

458 Pietro Daniel Omodeo Efemeridi e critica all'astrologia tra filosofia naturale ed etica: La contesa tra Benedetti e Altavilla nel tardo Rinascimento torinese

459 Simone Mammola Il problema della grandezza della terra e dell'acqua negli scritti di Alessandro Piccolomini, Antonio Berga e G. B. Benedetti e la progressiva dissoluzione della cosmologia delle sfere elementari nel secondo '500 
460 Stefano Bordoni Unexpected Convergence between Science and Philosophy: A debate on determinism in France around 1880

461 Angelo Baracca Subalternity vs. Hegemony - Cuba's Unique Way of Overcoming Subalternity through the Development of Science

462 Eric Hounshell \& Daniel Midena "Historicizing Big Data" Conference, MPIWG, October 31 - November 2, 2013 Report

463 Dieter Suisky Emilie Du Châtelet und Leonhard Euler über die Rolle von Hypothesen. Zur nach-Newtonschen Entwicklung der Methodologie

464 Irina Tupikova Ptolemy's Circumference of the Earth (TOPOI - Towards a Historical Epistemology of Space]

465 Irina Tupikova, Matthias Schemmel, Klaus Geus Travelling along the Silk Road: A new interpretation of Ptolemy's coordinates

466 Fernando Vidal and Nélia Dias The Endangerment Sensibility

467 Carl H. Meyer \& Günter Schwarz The Theory of Nuclear Explosives That Heisenberg Did not Present to the German Military

468 William G. Boltz and Matthias Schemmel Theoretical Reflections on Elementary Actions and Instrumental Practices: The Example of the Mohist Canon (TOPOI - Towards a Historical Epistemology of Space]

469 Dominic Olariu The Misfortune of Philippus de Lignamine's Herbal or New Research Perspectives in Herbal Illustrations From an Iconological Point of View 